\title{
Surge-front propagation and velocities during the early-1993-95 surge of Bering Glacier, Alaska, U.S.A., from sequential SAR imagery
}

\author{
James J. ROUSh, ${ }^{1}$ Craig S. Lingle, ${ }^{1}$ Righard M. GURItZ, ${ }^{1}$ Dennis R. FATLAND, ${ }^{1,2}$ \\ VERA A. VORONINA, \\ ${ }^{1}$ Geophysical Institute, University of Alaska Fairbanks, P.O. Box 757320, Fairbanks, AK 99775-7320, U.S.A. \\ E-mail:jroush@gi.alaska.edu \\ ${ }^{2}$ Vexcel Corporation, 4909 Nautilus Court, Boulder, CO 80301-3242, U.S.A. \\ ${ }^{3}$ SAPLabs Inc., 3410 Hillview Ave., Palo Alto, CA 94304, U.S.A.
}

\begin{abstract}
The initiation and propagation of the 1993-95 surge of Bering Glacier, Alaska, U.S.A., was observed using ERS-1 synthetic aperture radar (SAR) imagery. Images were acquired before and during the surge, between November 1992 and October 1993. Terrain-corrected and co-registered imagery was used to measure the propagation of the surge front. Surface undulations interpreted to be evidence of accelerated flow, indicating surge initiation in late winter, were observed in the 26 March 1993 image. From 19 May to 25 August 1993, the mean propagation velocity of the surge front was $90 \mathrm{~m} \mathrm{~d}^{-1}$. The surge reached the terminus shortly after 25 August 1993. The central area of the calving terminus then advanced into proglacial Vitus Lake at a mean rate of $19 \mathrm{~m} \mathrm{~d}^{-1}$ between 9 August and 18 October 1993. Feature matching was used to measure discrete velocity vectors between 9 August and 13 September; the vectors were kriged onto a uniform grid and used to compute the principal strain rates. Shattering of the calving front and dramatically increased iceberg calving were accompanied by high compressive strain rates immediately up-glacier from the calving front.
\end{abstract}

\section{INTRODUGTION}

Bering Glacier, Alaska, U.S.A. (Fig. 1), one of the world's largest temperate glaciers, with a length of $180 \mathrm{~km}$ and an area of approximately $5200 \mathrm{~km}^{2}$, descends from Bagley Ice Valley in the Saint Elias-Chugach Mountains to the Gulf of Alaska coast. It is also a surge-type glacier that has surged roughly once every 20-30 years (Molnia, 1993). Surges have occurred at irregular intervals, however. The two surges prior to 1993, occurring in 1957-60 and 1965-67 (Post, 1972), were separated by only a 5 year period of quiescence, and a "false start" occurred in 1981 (personal communication from A. Post, 1993). Despite concerns that Bering Glacier could undergo catastrophic tidewater retreat if exposed to the Gulf of Alaska (Molnia and others, 1990), the onset of a new surge was observed during a field program in June 1993 (Lingle and others, 1993; Molnia, 1993).

Quasi-periodic surging, during which flow rates increase by up to 100 times normal for $\sim 1$ to several years following a period of quiescence on the order of 10-100 years (Meier and Post, 1969; Post, 1969; Paterson, 1994), remains among the foremost problems of glacier mechanics. Considerable light was shed on this phenomenon by the study of the 1982-83 surge of Variegated Glacier, Alaska, which demonstrated that the surge was characterized by a transformation of the subglacial hydraulic system, resulting in a build-up of high subglacial water pressure that facilitated rapid basal motion (Kamb and others, 1985; Kamb, 1987; Raymond, 1987). Of the $>200$ surge-type glaciers identified from aerial photography in the mountain ranges of southern Alaska and Yukon, Canada (Post, 1969), only a small number have been observed surging (e.g. Post, 1960; Kamb and others, 1985; Echelmeyer and others, 1987; Harrison and others, 1994; Molnia and Post, 1995). Of these, Variegated Glacier has been studied in the greatest detail (e.g. Bindschadler and others, 1977; Bindschadler, 1982; Harrison and others, 1986; Raymond and others, 1987). Questions remain regarding the physical nature of the surge process. Larger glaciers, such as Bering, or glaciers located in different climatic regimes are of special interest.

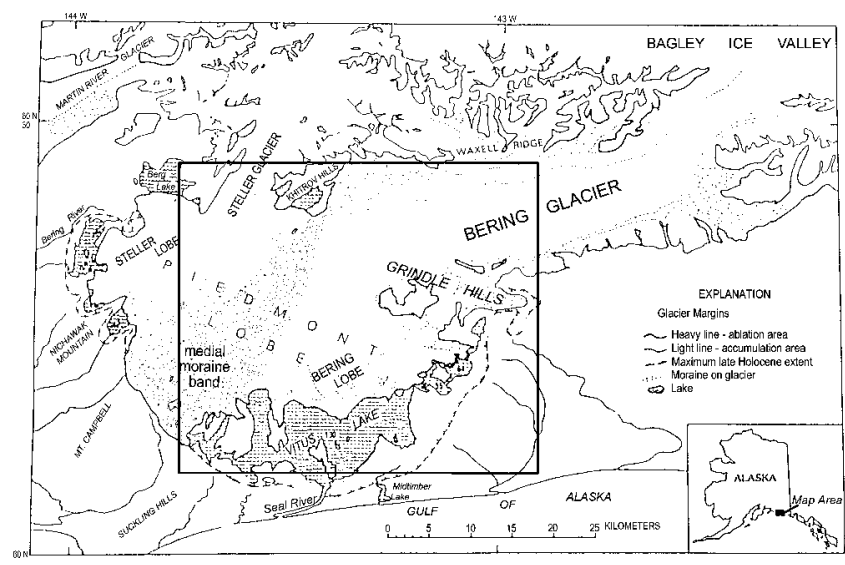

Fig. 1. Location of Bering Glacier, adapted from Molnia and Post (1995). The box is the SAR subscene area in Figures 2-5 and 7-9. 


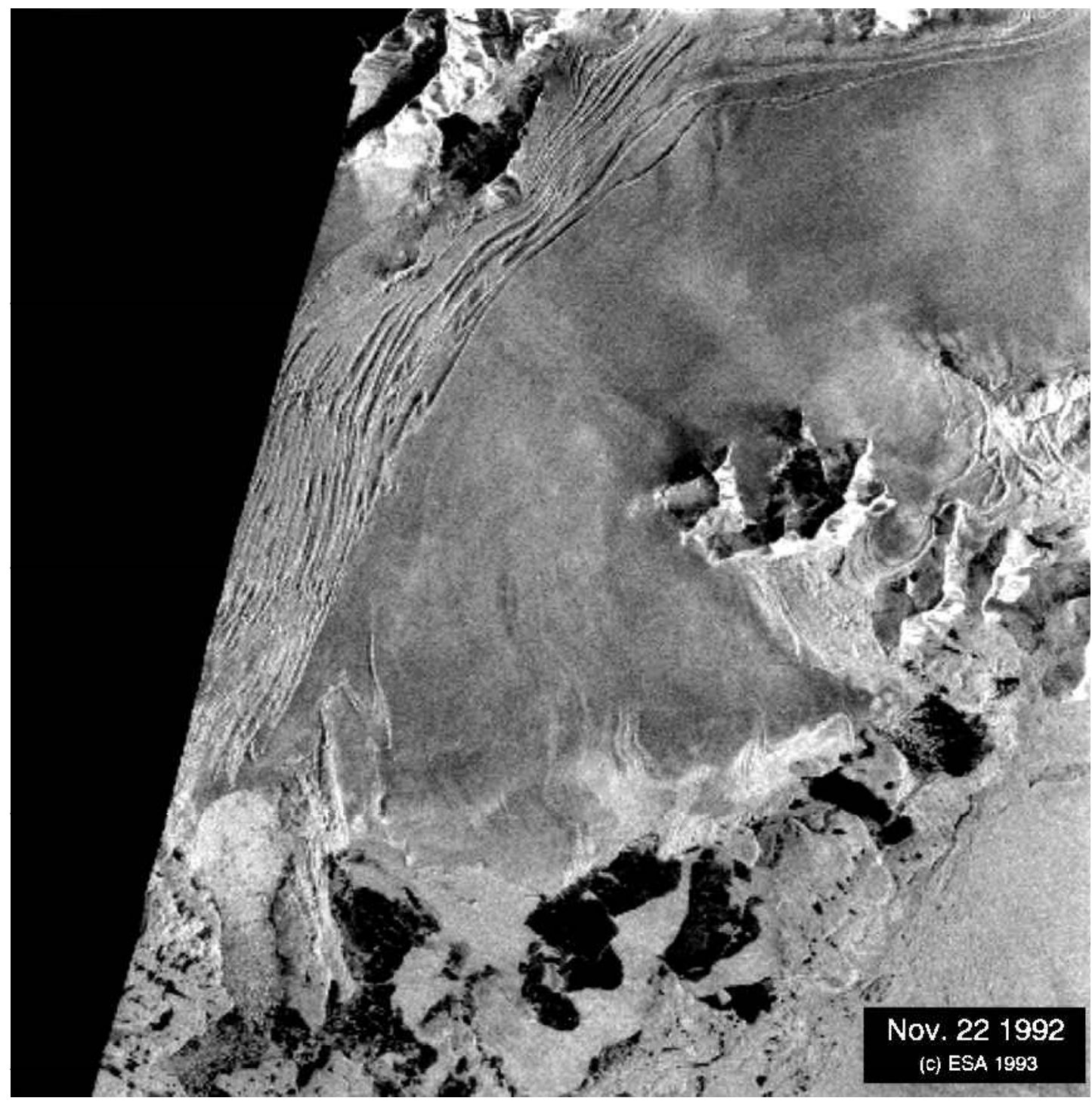

Fig. 2. A SAR subscene of lower Bering Glacier acquired on 22 November 1992, prior to surge onset. Note the smooth surface of the glacier. Figures 2-5 have been co-registered, and north is "up". Figures 2, 4 and 5 have been terrain-corrected. The direction of ice flow is from the upper right to the terminus, adjacent to the lake at bottom center. The subscene is $30.7 \mathrm{~km}$ north to south (top to bottom), and the same distance east to west (right to left). The subscenes in Figures 3-5 have the same dimensions.

European Remote-sensing Satellite-1 (ERS-1) synthetic aperture radar (SAR) images of Bering Glacier were terrain-corrected to eliminate the geometric distortions inherent in side-looking SAR; this included geocoding and co-registration to a digital elevation model (DEM) in a Universal Transverse Mercator (UTM) projection. The propagation of the surge front and the advance rate of the terminus were measured using the terrain-corrected imagery. Velocities and principal strain rates on the lower glacier were measured using two images from an exact repeat orbit that were not terraincorrected, in order to preserve higher resolution.

\section{ONSET AND PROPAGATION OF SURGE}

Figures 2-5 show lower Bering Glacier at selected times before and during the surge. Figure 1 (box) shows the location of these SAR subscenes relative to the entire glacier. Most of Bagley Ice Valley, the main accumulation area of Bering Glacier, is not shown (for SAR observations and analysis of Bagley Ice Valley during the surge, see Fatland and Lingle, 2002). Features described here were observed in the field during overflights in June and July, 1993 and 1994.

Figure 2 depicts lower Bering Glacier on 22 November 1992, approximately 4 months before the apparent time of surge onset. The mountains near right center are the Grindle Hills (Fig. 1). The surface of the glacier is relatively smooth. The closely spaced lineations along the western (left) edge of the subscenes are medial moraines that have been folded during previous surges (Post, 1972), and which separate Bering Glacier from Steller Glacier (a major tributary that is out of view to the west). The terminus of the glacier appears as the sharp difference in brightness at the bottom of the images where the glacier calves into proglacial Vitus Lake. The bright arcuate bands perpendicular to the terminus are medial moraines.

Figure 3 shows the lower glacier on 26 March 1993, soon after the onset of the surge. (This image could not be terrain-corrected because of errors in the original SAR data.) No images are available between 22 November 1992 and 26 March 1993. The dark glacier surface at the center of the Bering piedmont lobe is thought to be caused by the presence of water in the surface snow. Obvious displacement 


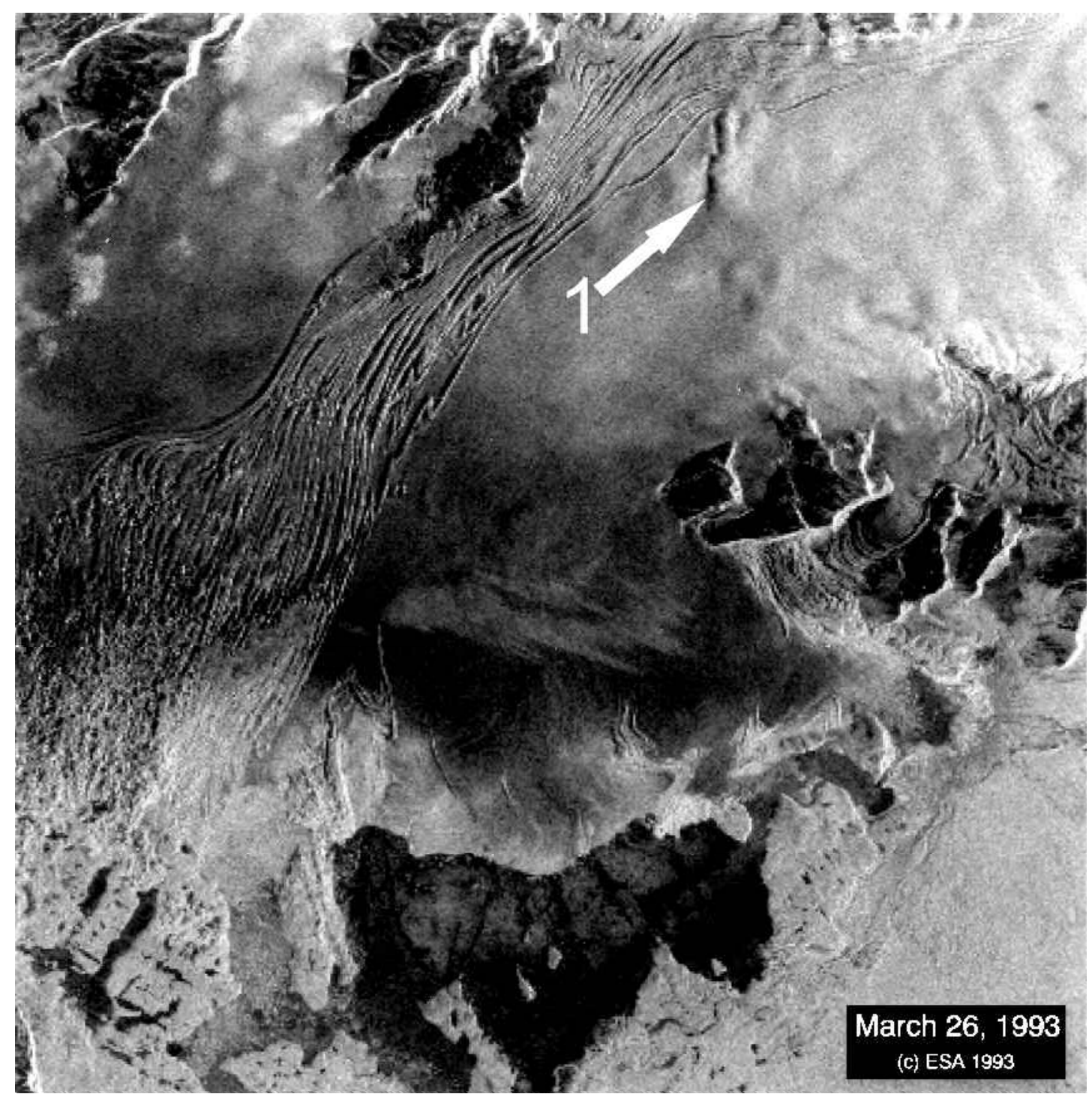

Fig. 3. Lower Bering Glacier on 26 March 1993, relatively soon after surge onset. Undulations on the glacier surface have appeared in the central valley, north of the Grindle Hills, and are most pronounced over an apparent bedrock high just south of the Khitrov Hills ( arrow 1, cf. Fig. 2).

had not yet occurred, but the surface had taken on a perceptibly hummocky appearance north of the Grindle Hills (top right), suggesting the onset of accelerated motion (Gudmundsson and others, 2003). This is discussed further below under "Time and Area of Onset".

By 25 August (image not shown), the western end of the terminus, near the surface debris band, had begun advancing into Vitus Lake. Across the remainder of the ice front, the surge had not quite reached the terminus. On 24 August, Bering Glacier was observed during a low-altitude flight by K. Echelmeyer and M. Nolan, of the Geophysical Institute, University of Alaska Fairbanks. The widespread undulations distributed across the lower glacier surface were clearly visible in oblique aerial photographs taken by $\mathrm{M}$. Nolan (personal communication, 1993). The photos suggest the undulations were roughly tens of meters to $100 \mathrm{~m}$ in height. The surface of the piedmont lobe contrasted strongly with the smooth, near-stagnant surface observed during late June 1993 (Lingle and others, 1993). According to M. Nolan (personal communication, 1993), heavy iceberg calving into Vitus Lake had not yet begun along most of the terminus by this date, except at the western end.
The propagation velocity of the surge front (see below) and the position of the front immediately above the terminus on 25 August (image not shown) indicate that the surge front reached the terminus shortly after that date. By 13 September (image not shown), the entire glacier surface had been deformed by the surge. SAR brightness variations across the surface of the glacier indicate widespread bulging and undulation. The crevasse fields seen developing in summer were widespread throughout the piedmont lobe and main trunk farther upstream. The arcuate medial moraines intersecting the terminus were obliterated. Heavy calving resulted in a continuous band of brash ice and icebergs near the terminus.

By 18 October (Fig. 4) the terminus was advancing across its entire length, most notably into the central and western portions of Vitus Lake, marked "4". Warping of the medial moraines above the western inlet of Vitus Lake (at left) was more pronounced. Active calving was occurring and the western (left) two-thirds of Vitus Lake was filled with icebergs. The ice is seen flowing around and over an area of elevated subglacial bedrock near the western end of the terminus, marked "1" (cf. Fig. 2). The terminus is advancing over a point of land (arrow 2) (cf. Fig. 2). Heavy crevassing 


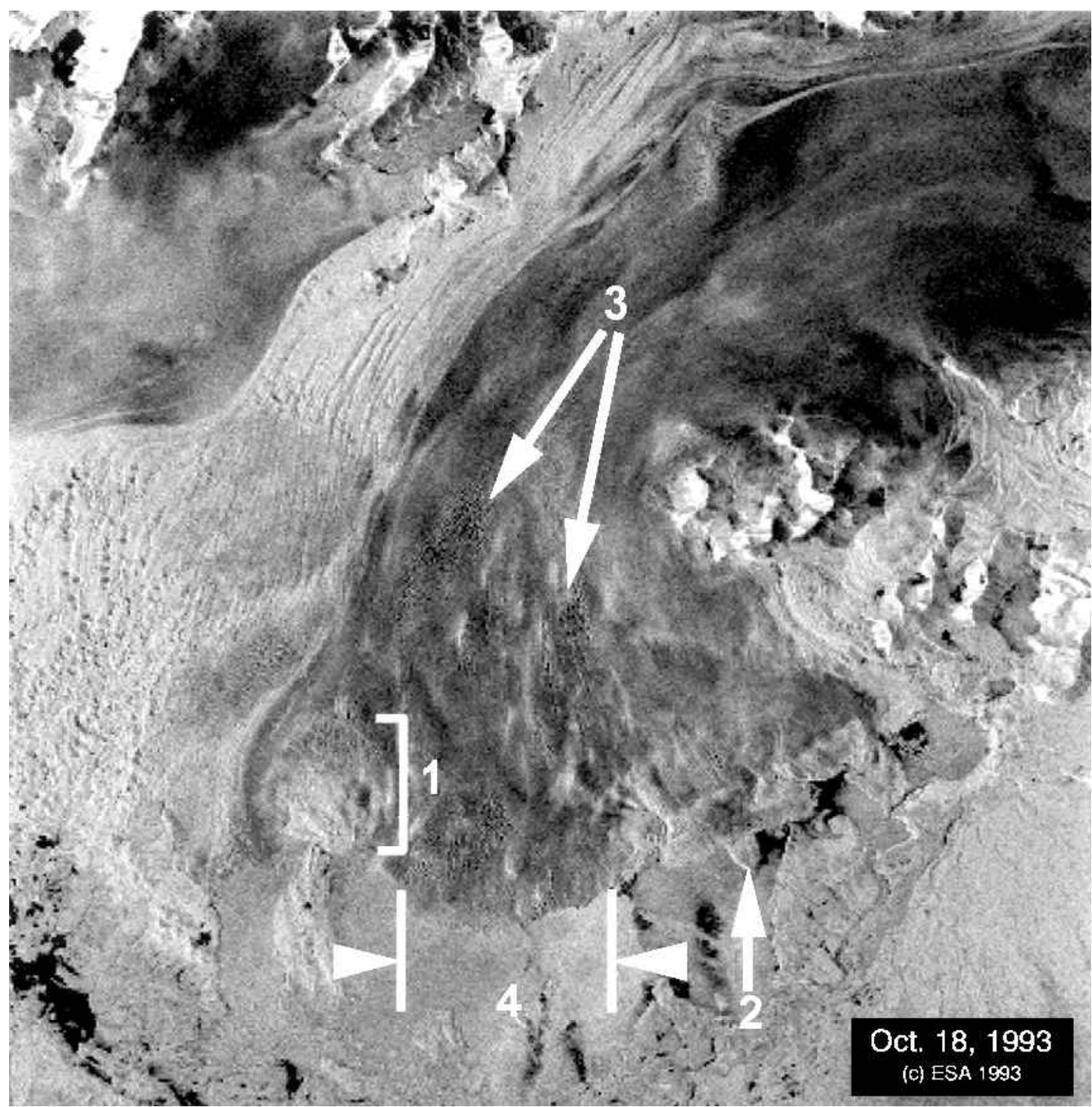

Fig. 4. By 18 October 1993 the entire terminus was advancing, most significantly in the central area of Vitus Lake (bracket 4), and the entire lower glacier was heavily fractured by the surge. Ice flow around elevated subglacial bedrock can be seen near the western end of the terminus (bracket 1; cf. Figs 2 and 3). Arrow 2 indicates ice advancing over a point of land (cf. Fig. 2). Arrowes 3 indicate two (of many) areas of pronounced crevassing.

had become widespread and pronounced (see, e.g., arrows labeled "3"). Field observations indicated that the crevasses were typically orthogonal.

\section{PROPAGATION VELOGITY AND TERMINUS ADVANGE RATE}

The terrain-corrected SAR images of Bering Glacier were used to measure the propagation velocity of the surge front and the rate of advance of the terminus into proglacialVitus Lake. Four sequential positions of the surge front are shown in Figure 5. The surge front is defined as the leading (downglacier) edge of the area of bulges on the glacier surface appearing in Figure 5 (from 19 May 1993). Observations made both in the field and with SAR imagery showed that the surge propagated to the terminus as a distributed region of ice bulges on the glacier surface, rather than as a single surge front as in the case of the 1982-83 surge of the much smaller and narrower Variegated Glacier (Kamb and others, 1985). By 13 September (image not shown) the surge front had reached the terminus, which was advancing rapidly.
The propagation velocity of the surge front was determined from sequential measurements of its mean position between 19 May and 25 August 1993 (Fig. 5). The mean position was determined by defining a polygon with a baseline in Vitus Lake parallel to the east--west UTM axis and north-south sides parallel to the north-south UTM axis; i.e. the sides of the polygon extend from the ends of the baseline to the opposite ends of the surge front. The polygon was closed using the irregular boundary of the surge front. The area of the polygon was determined by numerical integration. The mean position of the surge front with respect to the baseline was the height of the rectangle having a straight-line boundary parallel to the baseline, and area equal to the area of the polygon. The propagation velocity was then estimated as the change in the mean position of the surge front between successive images divided by the time difference.

The surge front advanced $2.6 \mathrm{~km}$ between 19 May and 23 June 1993; the mean propagation velocity was $75 \mathrm{md}^{-1}$. Between 23 June and 9 August 1993 the surge front advanced by $4.4 \mathrm{~km}$ at a mean velocity of $93 \mathrm{~m} \mathrm{~d}^{-1}$. Between 9 August and 25 August 1993 the surge front advanced $1.8 \mathrm{~km}$ at a 


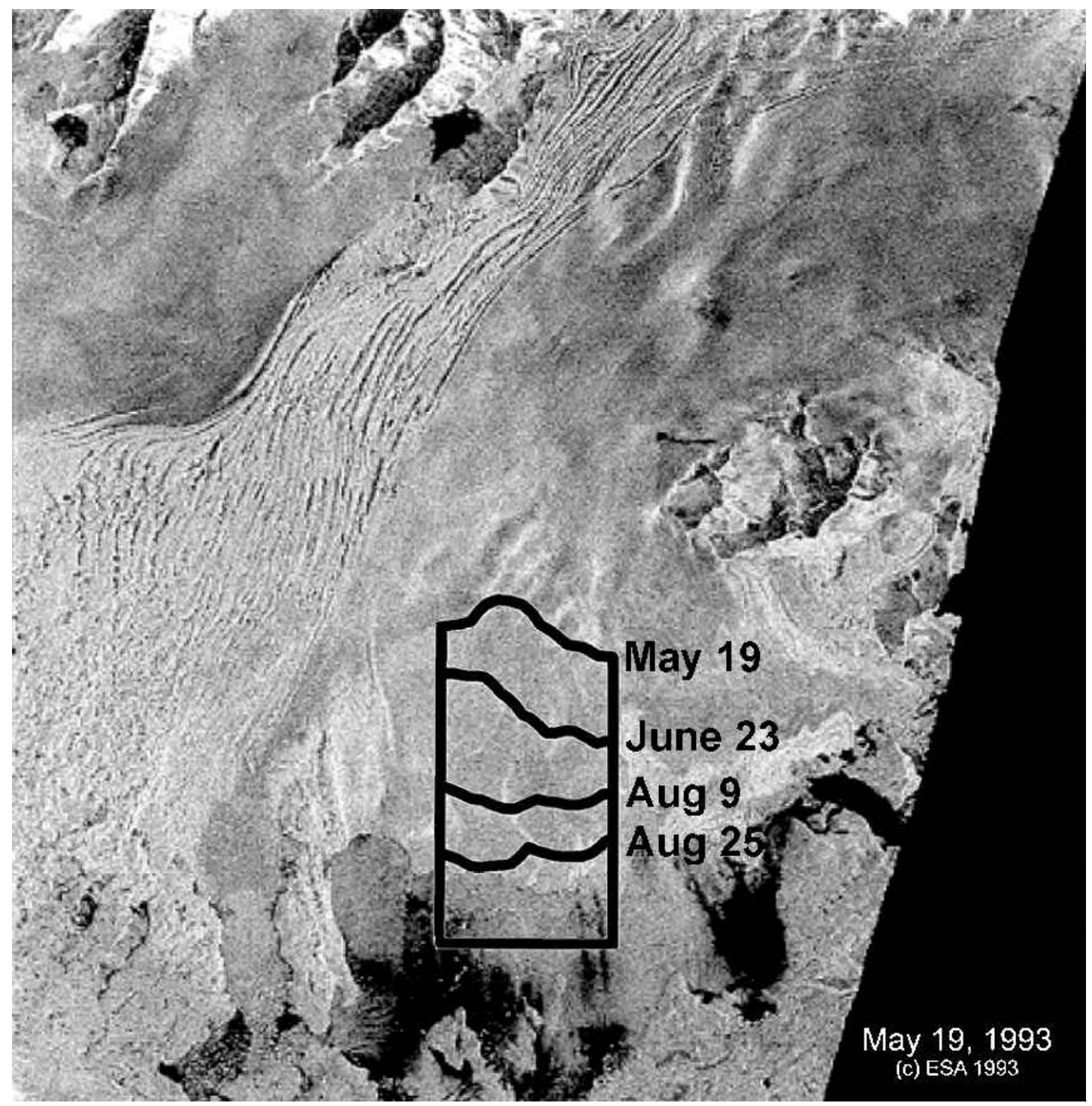

Fig. 5. Four sequential surge-front positions overlaid on a SAR subscene of lower Bering Glacier acquired on 19 May 1993, illustrating how polygons were used to measure the propagation velocity of the surge front. ( The terminus and surge-front positions are digitized to an accuracy of one pixel, $30 \mathrm{~m}$. The line widths shown are exaggerated for clarity.)

mean velocity of $112 \mathrm{~m} \mathrm{~d}^{-1}$. The mean propagation velocity from 19 May to 25 August was $90 \mathrm{~m} \mathrm{~d}^{-1}$. Independent remeasurement between two of these successive images indicated that these propagation velocity estimates could be repeated to within about $14 \%$. Uncertainty was caused by the irregular and somewhat diffuse nature of the surge front.

The maximum rate of advance of the terminus of Bering Glacier, through 18 October 1993, occurred in central Vitus Lake. Three successive positions of the terminus in this area are shown in Figure 6. The mean rate of terminus advance was measured as described for the surge front. (Note that, because of iceberg calving, the rate of terminus advance was less than the ice-flow velocity immediately up-glacier from the terminus.) Between 9 August, shortly before the surge front reached the terminus, and 13 September, the central terminus advanced by $0.4 \mathrm{~km}$; the mean advance rate was $12 \mathrm{~m} \mathrm{~d}^{-1}$. Between 13 September and 18 October, the central terminus advanced by $0.9 \mathrm{~km}$; the mean advance rate was $27 \mathrm{~m} \mathrm{~d}^{-1}$. The mean rate of advance of the central terminus from 9 August to 18 October was $19 \mathrm{~m} \mathrm{~d}^{-1}$.

Advance rates of the entire terminus were, on average, somewhat less than those of the central terminus. Between 9 August and 13 September, the terminus advanced $0.3 \mathrm{~km}$ on average; the mean advance rate was $8.3 \mathrm{~m} \mathrm{~d}^{-1}$. Between 13 September and 18 October, the terminus advanced $0.5 \mathrm{~km}$ on average; the mean advance rate was $14 \mathrm{~m} \mathrm{~d}^{-1}$. Across the entire Bering terminus (not just within the box shown in Fig. 5), the mean rate of advance between 9 Aug ust and 18 October was $11 \mathrm{~m} \mathrm{~d}^{-1}$.

\section{ICE VELOCITIES}

Velocities were measured on the lower glacier by co-registering subscenes from two images acquired from an exact repeat orbit on 9 August and 13 September 1993, during a 35 day ERS-1 orbit cycle (Voronina and others, 1995). This was the time interval during which the surge front reached the terminus of the glacier. The images were visually coregistered, to within approximately one pixel, using fixed topographic features. Resolution was maximized by using complex, full-resolution, slant-range images. These images have pixel dimensions of $7.9 \mathrm{~m}$ (range) by $3.9 \mathrm{~m}$ (azimuth). Power-domain averages over 5 pixels in the azimuth direction were taken, increasing that pixel dimension to $19.5 \mathrm{~m}$. The $7.9 \mathrm{~m}$ slant-range pixels correspond to approximately 


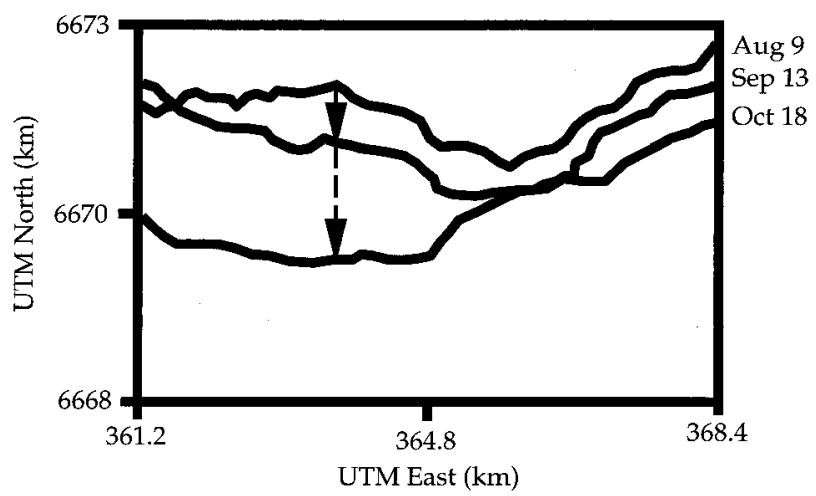

Fig. 6. Sequential positions of the terminus in the area of maximum advance in central Vitus Lake, plotted in UTM coordinates.

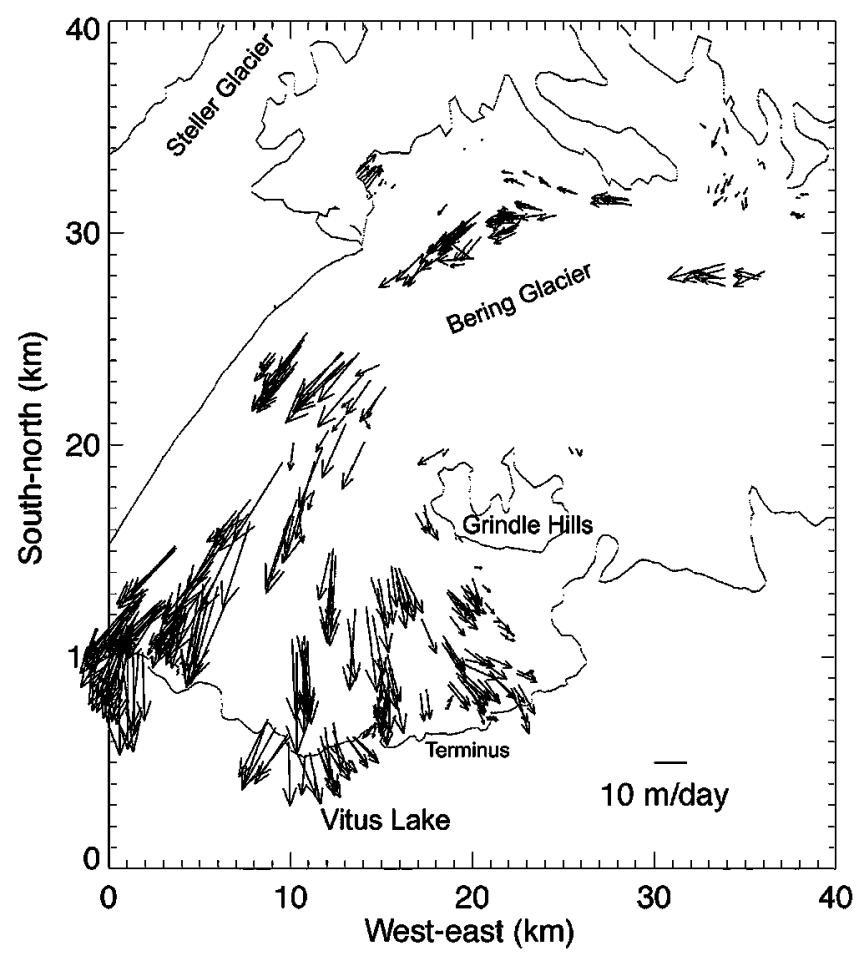

Fig. 7. Velocity vectors ( $m d^{-1}$ ) on Bering Glacier, derived from feature matching using images acquired on 9 August and 13 September 1993. The higher concentration of vectors on the lower glacier corresponds to the higher density of recognizable features on the rougher, chaotically crevassed surface. (From Voronina and others, 1995.)

$20 \mathrm{~m}$ in ground range, so the averaged pixels had aspect ratios close to 1 .

The displacements of features on the moving glacier, which could be recognized in both subscenes, were then measured directly. (SAR interferometry (e.g. Fatland and Lingle, 1998) could not be used because of the rapid motion and deformation of the ice.) The measured displacements, expressed as velocity in $\mathrm{m} \mathrm{d}^{-1}$, are shown in Figure 7. The errors resulting from a combination of SAR imaging geometry, image mis-registration, and ambiguities in feature identification are estimated to be less than about $10 \%$ of the velocities, which were derived from relatively large ice displacements.

The measured velocity vectors (Fig. 7) were then interpolated onto the nodes of a $1 \mathrm{~km}$ square grid, using the geostatistical method of ordinary kriging (e.g. Isaaks and

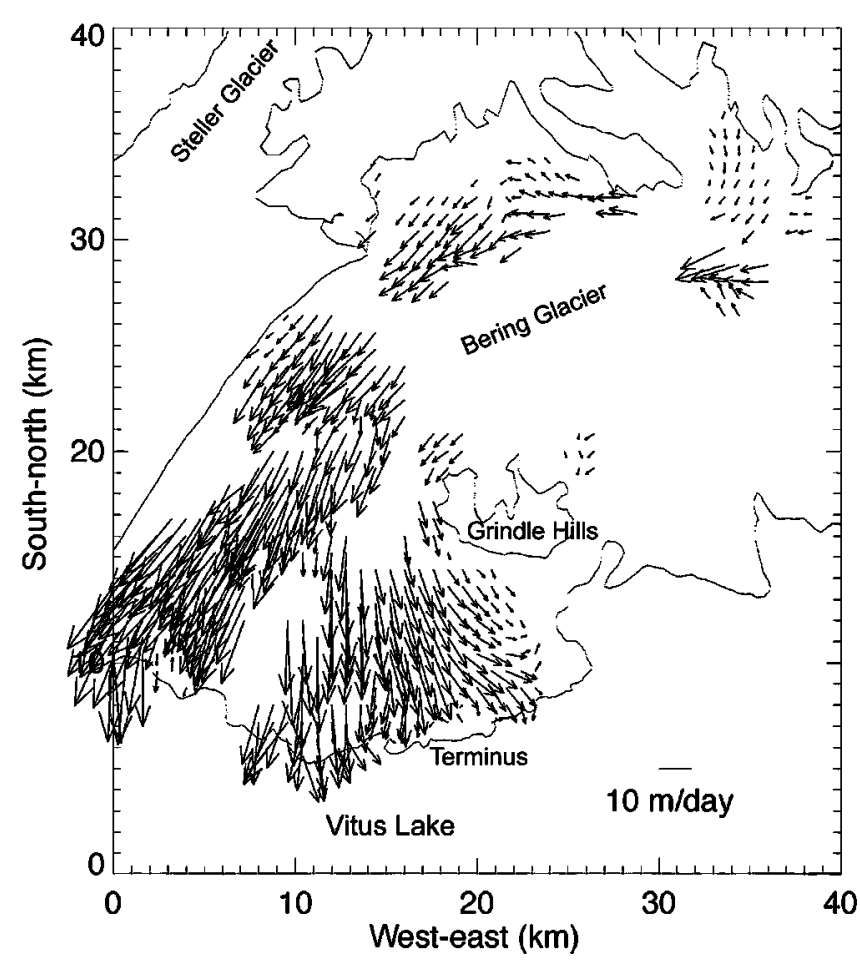

Fig. 8. Velocity vectors ( $m d^{-1}$ ) on Bering Glacier (9 August13 September 1993), kriged onto a $1 \mathrm{~km}$ by $1 \mathrm{~km}$ square grid. ( The north-south and east-west components were kriged separately.) Only the vectors with estimated errors $<30 \%$ of the total velocity were retained. The highest velocities were immediately up-glacier from Taslich Arm (at lower left), where the surge front first reached the calving front. (From Voronina and others, 1995.)

Srivastava, 1989). Spatial structure was estimated by computing two variograms for the two horizontal components of the velocity vectors, which were then kriged independently. The results are shown in Figure 8. The error of each of the kriged velocity vectors has two components: one is due to the measurement errors described above; a second, generally larger component is due to the spatial distance between the measured vectors and the kriged nodes. The first component was propagated through the kriging equations, using standard methods. The second component was estimated from the variance at the kriged nodes.

Only the vectors having combined errors $<30 \%$ of the total velocity were retained in Figure 8 , which shows that many of the velocity vectors were in the $10-20 \mathrm{~m} \mathrm{~d}^{-1}$ range. The maximum ice velocity shown in Figure 7 is $59 \mathrm{~m} \mathrm{~d}^{-1}$ (ordinary kriging did not result in extrapolation beyond the measured velocities). This can be compared to the quiescent period between surges, when the surface velocities were of the order of $1 \mathrm{~m} \mathrm{~d}^{-1}$ (personal communication from R. Krimmel, 1993) or less (Post, 1972). Figures 7 and 8 show that the ice velocities were substantially less than the propagation velocity of the surge front, as pointed out by Kamb and others (1985) and Raymond and others (1987) for Variegated Glacier.

Figure 9 shows the horizontal principal strain rates $\left(\mathrm{d}^{-1}\right)$ on lower Bering Glacier between 9 August and 13 September 1993, derived from the gridded velocities shown in Figure 8. The solid lines represent horizontal compressive strain rates; the dotted lines represent horizontal extensive strain rates. Because principal strain rates are functions of the velocity gradients (e.g. Paterson, 1994), the errors were magnified during this computation. The errors were propagated, as 


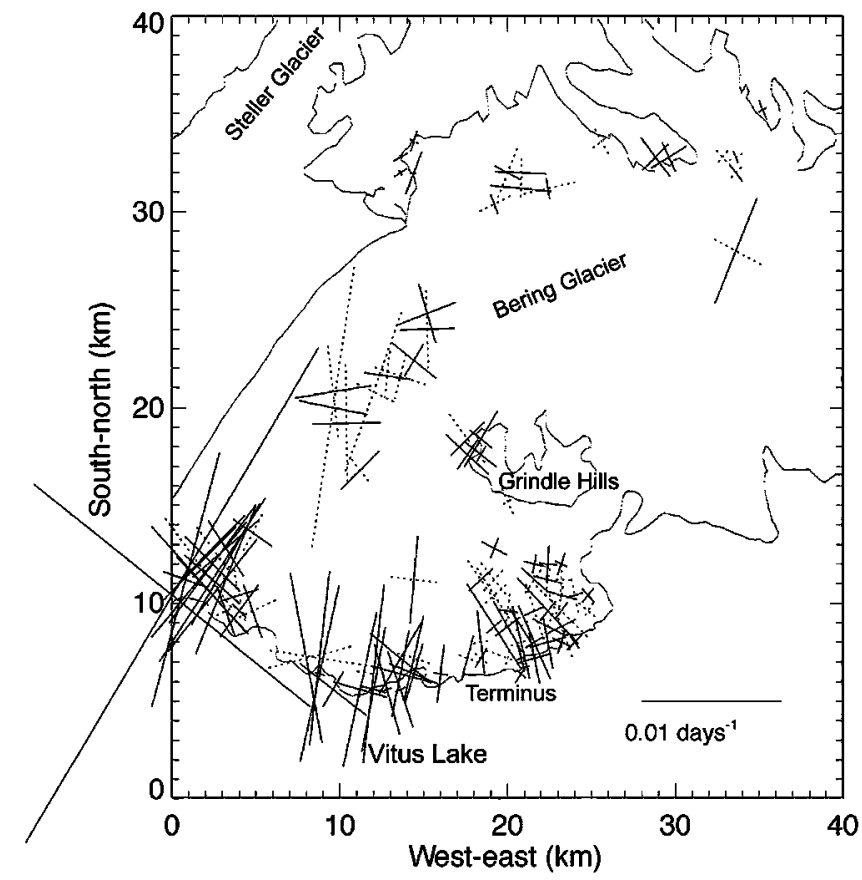

Fig. 9. Horizontal principal strain rates (d $d^{-1}$ on Bering Glacier, 9 August-13 September 1993, computed from the gridded velocities shown in Figure 8. The solid and dotted lines represent compression and extension, respectively. Horizontal compressive strain rates, accompanied (by implication) by high extensive vertical strain rates, were predominant as down-glacier propagation of the surge caused rapid thickening near the calving front.

described above for the velocities, and only those horizontal principal strain rates for which the estimated errors were $<80 \%$ are shown in Figure 9. The horizontal principal strain-rate field is considerably less dense than the kriged velocity field (Fig. 8) due to this error criterion.

Figure 9 shows that although both horizontal extensive and compressive principal strain rates occurred at many locations, compression in both directions was dominant near the calving front. In many cases, both of the horizontal principal strain rates were compressive, which implies from conservation of mass - that high extensive vertical strain rates predominated as the glacier thickened near the terminus. Figure 9 shows that shattering of the calving front and the dramatic acceleration of iceberg calving that occurred when the surge front arrived were accompanied by high compressive horizontal principal strain rates immediately up-glacier from the calving front.

\section{TIME AND AREA OF ONSET}

The smoothness of the glacier surface on 22 November 1992 (Fig. 2) reflects the slow-moving nature of the piedmont lobe during the quiescent phase (Post, 1972). By 26 March 1993, a sharp bulge had appeared at the location marked "1" in Figure 3 (see Lingle and others, 1993, fig. 5, for photo). Also, surface undulations had developed on the glacier surface north and northeast of the Grindle Hills. These surface undulations, which are not evident in the 22 November 1992 image (Fig. 2), show that accelerated basal motion was in progress in this area by 26 March 1993. Gudmundsson and others (2003) show that a similar increase in the amplitude ratio of surface to bedrock undulations occurred as a result of increased basal motion during the 1994 surge of Tungnaárjökull, Iceland. The SAR images thus show that the surge began between 22 November 1992 and 26 March 1993, most likely during late winter 1993. The image of Figure 3 appears to have been acquired soon after surge onset.

The surface undulations in the northeast (top right) area of Figure 3 suggest that the area of surge onset was up-glacier from the top right edge of the inset box shown in Figure 1. Field observations from a small aircraft in late June 1993 (Lingle and others, 1993), however, revealed no sign that the surge had yet affected the area further up-glacier where Bering Glacier descends from Bagley Ice Valley (Fig. 1, top right). This suggests that the area of surge onset was the upper reach of Bering Glacier, roughly $50 \mathrm{~km}$ up-glacier from the calving front. If so, this would be roughly the area where the bed of Bering Glacier descends below sea level (Molnia, 1993).

\section{DISGUSSION AND SUMMARY}

The ERS-1 SAR yielded sequential imagery of the surge of Bering Glacier through the heavy clouds that severely limit other space-borne sensors in the coastal mountains of Alaska. The surge started during winter, between 22 November 1992 and 26 March 1993, most likely in late winter 1993. Subsequently, the surge propagated to the terminus as a distributed region of ice bulges on the glacier surface. The mean propagation velocity of the Bering surge front, measured using terrain-corrected, geocoded and co-registered images, was $75 \mathrm{~m} \mathrm{~d}^{-1}$ between 19 May and 23 June 1993, $93 \mathrm{~m} \mathrm{~d}^{-1}$ between 23 June and 9 August, and $112 \mathrm{~m} \mathrm{~d}^{-1}$ between 9 August and 25 August 1993. This is comparable to the propagation velocity of the surge front on Variegated Glacier $\left(80 \mathrm{~m} \mathrm{~d}^{-1}\right.$ from 17 May to 13 June 1983 (Kamb and others, 1985)); Peters Glacier, Alaska Range (110-24 $\mathrm{m} \mathrm{d}^{-1}$ from April to mid-September 1986 (Echelmeyer and others, 1987)); and West Fork Glacier, Alaska Range (78 $\mathrm{m} \mathrm{d}^{-1}$ from 29 January to 18 March 1988 (Harrison and others, 1994)). Ice velocities on lower Bering Glacier were substantially less than the surge-front propagation velocity, which is a necessary consequence of the wavelike propagation of the surge front, as noted by Kamb and others (1985) and Raymond and others (1987).

High compressive horizontal principal strain rates, accompanied (by implication) by high extensive vertical strain rates, were predominant near the terminus as propagation of the surge front caused rapid thickening of the lower piedmont lobe. After the surge front reached the terminus, shattering of the calving front and dramatically accelerated iceberg calving were accompanied by high horizontal compressive principal strain rates immediately upglacier from the calving front.

The terminus of Bering Glacier advanced at a mean rate of $11 \mathrm{~m} \mathrm{~d}^{-1}$ between 9 August and 18 October 1993 along its entire $34 \mathrm{~km}$ perimeter, during and after the time when the surge front reached the terminus. A maximum advance rate of $19 \mathrm{~m} \mathrm{~d}^{-1}$ was measured in the central area of the terminus during the same time period.

The seasonality of surge onset is linked to the relationships between subglacial hydrology and the drainage of surface and stored englacial water to the bed (Lingle and Fatland, 2003). In the case of Variegated Glacier, the surge started in January 1982, when surface melting and rain were absent or negligible (Kamb and others, 1985). The first indi- 
cations of the Bering Glacier surge are in the image of 26 March 1993 (Fig. 3), which also indicates wet surface snow - although on the lower piedmont lobe, not in the apparent area of surge onset. Variegated Glacier, which is in the same climatic regime, did not undergo its characteristic spring acceleration in the years prior to the 1982-83 surge until mid-June (Harrison and others, 1986). Thus, March is likely to be still within "hydrological winter" on Bering Glacier, from the point of view of subglacial hydrology. The surge of Peters Glacier apparently started at a similar time of year, that is, prior to 18 April 1986 (Echelmeyer and others, 1987). The surge of West Fork Glacier started near or soon after the end of the 1987 melt season, and may have been in its early stages on 25 August 1987 (Harrison and others, 1994). TheWest Fork surge is thus an exception to the apparent tendency of glacier surges to start during winter.

Following initiation, the Bering surge continued through summer 1993, indicating that the subglacial hydraulic system enabling fast flow was able to maintain itself throughout the summer period of high ablation and water drainage into the glacier. The surge of Variegated Glacier, by contrast, stopped during summer 1982, apparently due to the opening of an efficient drainage system caused by high surface-water input, then began again in October 1982, then came to a final halt in mid-July 1983 (Kamb and others, 1985). The surge of Peters Glacier, like the Bering surge, continued through summer 1986. The surge of West Fork Glacier lasted only about 10 months, and like the Variegated surge terminated in summer, on 6 July 1988.

The surge of Bering Glacier continued until July 1994, when the end of fast flow corresponded with an outburst flood of basal water (Roush, 1996). The surge reinitiated in spring 1995 and continued into the summer of that year before the final end of the 2 year surge (personal communication from S. Ranney, 1995; Roush, 1996). The duration of surges in Alaska-Yukon has typically been approximately 1-3 years (Post, 1972; Molnia, 1993).

\section{ACKNOWLEDGEMENTS}

This work was supported by the NASA Polar Research Program (grant NAGW-2827), the Alaska Space Grant Program and the NASA Cryospheric Sciences Program (grant NAGS11336). SAR data and image-analysis user tools were provided by the Alaska SAR Facility. We thank B. Molnia for inviting us to join his U.S. Geological Survey field parties at Bering Glacier during 1993-94, A. Post for many valuable discussions, R. Krimmel for discussions of his air photographs, M. Nolan for discussions of his air photographs and videotape acquired over Bering Glacier in late August 1993, and W. Harrison and $\mathrm{K}$. Echelmeyer for valuable suggestions and comments.

\section{REFERENGES}

Bindschadler, R. 1982. A numerical model of temperate glacier flow applied to the quiescent phase of a surge-type glacier. F. Glaciol., 28 (99), 239-265.

Bindschadler, R., W. D. Harrison, C. F. Raymond and R. Crosson. 1977. Geometry and dynamics of a surge-type glacier. f. Glaciol., 18(79), 181-194.

Echelmeyer, K., R. Butterfield and D. Cuillard. 1987. Some observations on a recent surge of Peters Glacier, Alaska, U.S.A. f. Glaciol., 33(115), 341-345.

Fatland, D. R. and C. S. Lingle. 1998. Analysis of the 1993-95 Bering Glacier (Alaska) surge using differential SAR interferometry. F. Glaciol., 44(148), $532-546$.

Fatland, D. R. and C. S. Lingle. 2002. InSAR observations of the 1993-95 Bering Glacier (Alaska, U.S.A.) surge and a surge hypothesis. F. Glaciol., 48(162), 439-451.

Gudmundsson, G. H., G. Aðalgeirsdóttir and H. Björnsson. 2003. Observational verification of predicted increase in bedrock-to-surface amplitude transfer during a surge. Ann. Glaciol., 36 (see paper in this volume).

Harrison, W. D., G. F. Raymond and P. MacKeith. 1986. Short period motion events on Variegated Glacier as observed by automatic photography and seismic methods. Ann. Glaciol., 8, 82-89.

Harrison, W. D., K. A. Echelmeyer, E. F. Chacho, C. F. Raymond and R. J. Benedict. 1994. The 1987-88 surge of West Fork Glacier, Susitna Basin, Alaska, U.S.A. F. Glaciol., 40 (135), 241-254.

Isaaks, E. H. and R. M. Srivastava. 1989. Applied geostatistics. New York, Oxford University Press.

Kamb, B. 1987. Glacier surge mechanism based on linked cavity configuration of the basal water conduit system. F. Geophys. Res., 92(B9), 9083-9100.

Kamb, B. and 7 others. 1985. Glacier surge mechanism: 1982-1983 surge of Variegated Glacier, Alaska. Science, 227(4686), 469-479.

Lingle, C. S. and D. R. Fatland. 2003. Does englacial water storage drive temperate glacier surges? Ann. Glaciol., 36 (see paper in this volume).

Lingle, C. S., A. Post, U. C. Herzfeld, B. F. Molnia, R. M. Krimmel and J. J. Roush. 1993. Correspondence. Bering Glacier surge and iceberg-calving mechanism at Vitus Lake, Alaska, U.S.A. F. Glaciol., 39(133), 722-727.

Meier, M. F. and A. Post. 1969. What are glacier surges? Can. 7. Earth Sci., 6(4), Part 2, 807-817.

Molnia, B. 1993. Major surge of the Bering Glacier. Eos, 74(29), 321-322.

Molnia, B. F. and A. Post. 1995. Holocene history of Bering Glacier, Alaska: a prelude to the 1993-1994 surge. Phys. Geogr., 16(2), 87-117.

Molnia, B. F., D. C. Trabant, A. Post and D. G. Frank-Molnia. 1990. Bering Glacier, Alaska: factors influencing the potential for an irreversible calving retreat. [Abstract.] Eos, 71(43), 1314.

Paterson, W. S. B. 1994. The physics of glaciers. Third edition. Oxford, etc., Elsevier

Post, A. S. 1960. The exceptional advances of the Muldrow, Black Rapids, and Susitna Glaciers. F. Geophys. Res., 65(11), 3703-3712.

Post, A. 1969. Distribution of surging glaciers in western North America. f. Glaciol., 8(53), 229-240.

Post, A. 1972. Periodic surge origin of folded medial moraines on Bering piedmont glacier, Alaska. 7. Glaciol., 11 (62), 219-226.

Raymond, C. F. 1987. How do glaciers surge? A review. 7. Geophys. Res., 92(B9), 9121-9134.

Raymond, C., T. Jóhannesson, T. Pfeffer and M. Sharp. 1987. Propagation of a glacier surge into stagnant ice. f. Geophys. Res., 92(B9), 9037-9049

Roush, J.J. 1996. The 1993-94 surge of Bering Glacier, Alaska, observed with satellite synthetic aperture radar. (M.Sc. thesis, University of Alaska Fairbanks.)

Voronina, V. A., D. R. Fatland and C. S. Lingle. 1995. Analysis of satellite synthetic aperture radar imagery of Alaska and Antarctic radar altimeter data acquired by the First European Remote Sensing Satellite (ERS-1). In Thirty-Sixth Semi-Annual Cray User Group Meeting, Fairbanks, Alaska, September 25-29, 1995. Proceedings. Shepherdstown, WV, Fine Point Editorial Services, $45-51$. 